\title{
Serum levels of interleukin-6 are not elevated in patients with Alzheimer's disease
}

\author{
Cornelia M van Duijn ${ }^{1}$, Albert Hofman ${ }^{1}$ and Lex Nagelkerken ${ }^{2}$ \\ 'Department of Epidemiology and Biostatistics, Erasmus University Medical School, Rotterdam (The \\ Netherlands) and 'The Department of Immunology, Institute for Experimental Gerontology TNO. Rijswijk \\ (The Netherlands)
}

(Received 28 July 1989; Revised version received I3 September 1989; Accepted 13 September 1989)

Key words: Interleukin-6; Alzheimer's disease; Acute-phase response

Serum levels of interleukin-6 (IL-6) were determined in 97 patients with clinically diagnosed Alzheimer's disease and 79 age- and sex-matched control subjects. Median serum levels of IL-6 did not differ signifcantly between Alzheimer patients $(8.6 \mathrm{U} / \mathrm{ml})$ and controls $(8.2 \mathrm{U} / \mathrm{ml})$. Median levels of serum IL-6 were similar for sporadic and familial patients. The concentration of IL- 6 was not associated with the severity of the dementia or the duration of the disease since first symptoms. According to these observations there is no evidence for a significant elevation in serum IL-6 in Alzheimer's disease.

In patients with Alzheimer's disease, extracellular amyloid fibrils accumulate in the cores of the senile plaques and in cerebral and meningeal microvessels [8]. Two lines of evidence suggest that the formation of amyloid deposits in Alzheimer's disease may be accompanied by an acute-phase response, the reaction of the body to tissue damage and inflammatory processes. First, the amyloid in the senile plaques has been demonstrated to be tightly associated with the acute-phase protein $\alpha 1$-antichymotrypsin $[1,2]$. Second, increased serum levels of the acute-phase proteins have been reported in patients with Alzheimer's disease [3, 7].

Recently, it has been demonstrated that the production of acute-phase proteins is at least in part mediated by two lymphokines, interleukin-1 (IL-1) and interleukin-6 (IL-6) $[5,6,15,16,17]$. These lymphokines are produced by a variety of cells and have several functions inside and outside the immune system [17]. The increased serum levels of IL-6 that have been demonstrated in patients rejecting their kidney transplantant [20], patients with serious skin injury [16], and in patients with rheumatoid arthritis $[11,21]$ indicate that inflammatory processes can be sensitively monitored by an IL- 6 bio-assay. Therefore, we have used this assay to study serum levels

Correspondence: C.M. van Duijn, Department of Epidemiology and Biostatistics, Erasmus University Medical School, P.O. Box 1738, 3000 DR Rotterdam, The Netherlands. 
of IL-6, as a serologic marker of disease and severity of dementia in 97 patients with clinically diagnosed Alzheimer's disease, and in 79 population control subjects.

Patients were derived from an epidemiological study of risk factors of clinically diagnosed Alzheimer's disease. For this study all early onset patients (diagnosis $\leqslant 70$ years) living in the 4 northern provinces of the Netherlands in whom the diagnoses was made in the period of January 1980 to July 1987 were ascertained [10]. Dementia's other than Alzheimer's disease (e.g. multi-infarct dementia, and dementia secondary to alcoholism, depression, metabolic disorders, epilepsy, Parkinson's disease, and other conditions) were excluded using a clinical history, neurological examination, and neuropsychological and laboratory tests [14]. For this study the diagnosis of Alzheimer's disease was confirmed independently. All patients fulfilled the following criteria: (1) slow progressive decline of intellectual function; (2) a score on the clinical dementia rating scale of more than 0.5 [12]; (3) a score on the short portable mental status questionnaire (SPMSQ) of less than 20 [18]; (4) a score of 7 or less on the Hachinski-scale [9]; and (5) no evidence for abnormalities on CT-scan other than cerebral atrophy, and no evidence for focal dysfunction in the EEG. For each patient a control subject matched for age (within 5 year age groups) and gender was

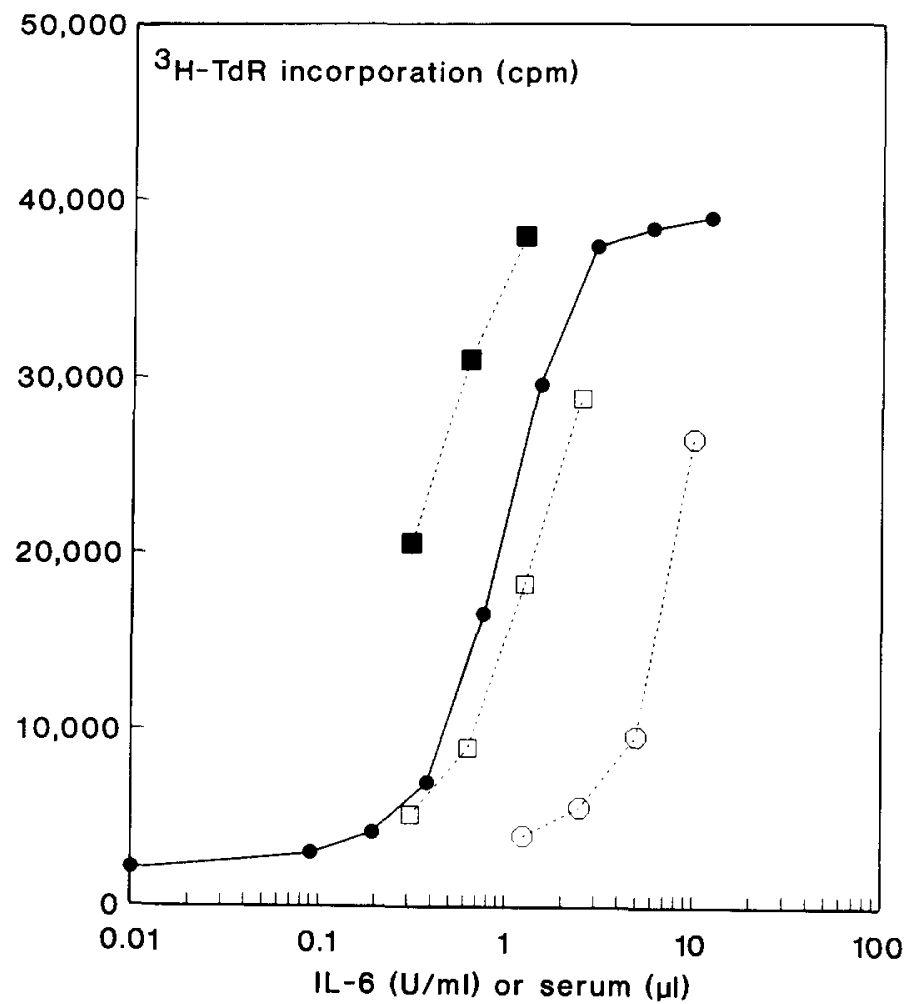

Fig. 1. Measurement of IL-6 in serum. Several amounts of human recombinant IL-6 $(\bullet)$, serum from one patient with Alzheimer's disease ( $O$ ), and serum from two controls ( $\square$ and $\square$ ) were compared with regard to their ability to induce proliferation by $\mathrm{B} 9$ cells. 
selected from the municipal place of residence of the patients. None of the control subjects showed signs of dementia as measured by the SPMSQ. 127 patients and 127 controls from the 4 Northern provinces participated in the initial study; serum samples were available for 97 patients $(76 \%)$ and 79 controls $(62 \%)$.

Serum levels of IL-6 were determined in stored serum samples $\left(-80^{\circ} \mathrm{C}\right)$ with the use of a bio-assay [16]. IL-6 dependent $\mathrm{B} 9$ hybridoma cells as well as human recombinant IL-6 were kindly provided by Dr. L. Aarden, Central Laboratory of the Blood Transfusion Service, Amsterdam. The cells were cultured in Iscoves' modified Dulbecco's medium (Seromed, Berlin, F.R.G.), supplemented with penicillin $(100 \mathrm{U} / \mathrm{ml})$, streptomycin $(100 \mu \mathrm{g} / \mathrm{ml}), 2 \mathrm{mM}$ L-glutamin, $5 \times 10^{-5} \mathrm{M} 2$-mercapto-ethanol and $5 \%$ (v/v) foetal calf serum (Seralab, Crawley Down, U.K.). Sera from patients with Alzheimer's disease and from control subjects were serially diluted in duplicate in the same medium in flat-bottom microtiter plates (Greiner, Nürtingen, F.R.G.). Five thousand B9 cells were added to each well and the final volume was adjusted to 200 $\mu \mathrm{l}$. After $66 \mathrm{~h}$ of culture, the cells were pulsed with $0.25 \mu \mathrm{Ci}\left[{ }^{3} \mathrm{H}\right]$ methyl-thymidine (spec. act. $2 \mathrm{CI} / \mathrm{mmol}$; Radiochemical Center, Amersham, U.K.). Six hours later, the cultures were terminated by harvesting the DNA on nitrocellulose filters (Skatron, Tranby, Norway). Filters were counted in toluene, containing $4 \mathrm{~g} / 1 \mathrm{PPO}$ and $0.05 \mathrm{~g} / 1$ POPOP. One unit IL-6/ml was defined as the concentration at which half-maximal proliferation was found; recombinant IL-6 served as a standard.

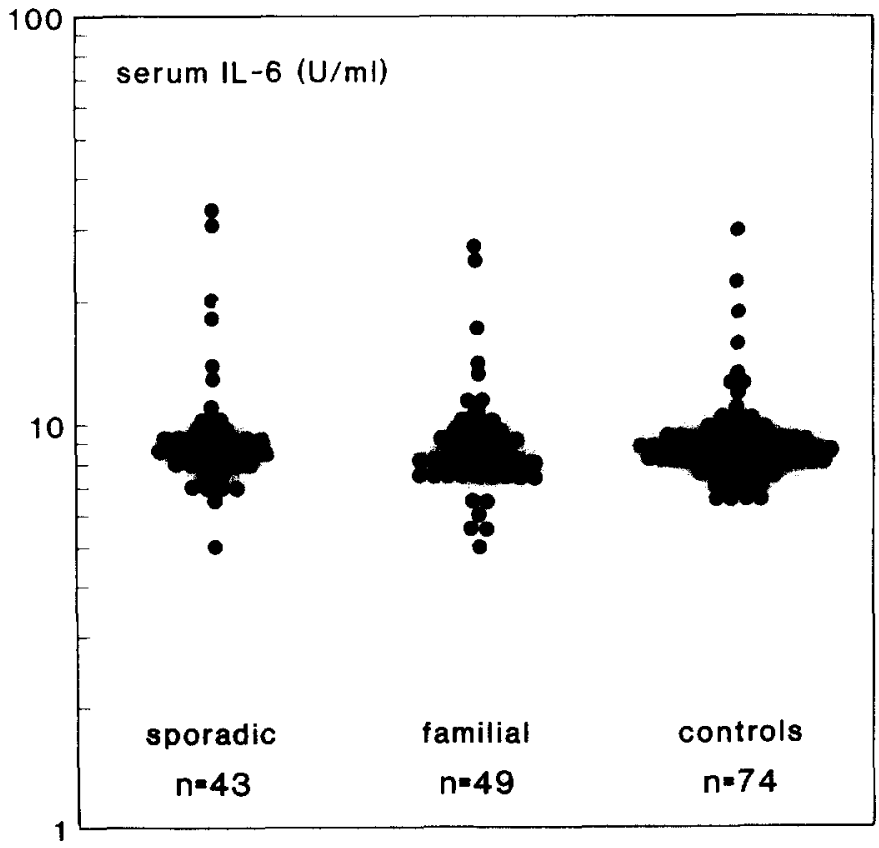

Fig. 2. Interleukin-6 (IL-6) in serum of Alzheimer patients and age- and sex-matched controls. 
As appears from Fig. 1, the B9 assay is highly sensitive to IL-6. The B9 cells proliferated in a dose-dependent manner in response to rIL-6. The assay detected levels of rIL-6 as low as $0.1 \mathrm{U} / \mathrm{ml}$. Maximal proliferation of the cells occurred in the presence of approximately $5 \mathrm{U} / \mathrm{ml}$. Parallel dose response curves were obtained when positive sera were diluted. These three individual sera numbered 1052, 2063 and 2082 were found to contain 25,96 and $650 \mathrm{U}$ IL-6/ml, respectively.

Median concentrations of serum IL-6 did not differ significantly $(P<0.40)$ between Alzheimer patients $(8.6 \mathrm{U} / \mathrm{ml}$, range: $4.6-34.0)$ and controls $(8.4 \mathrm{U} / \mathrm{ml}$, range: 5.8-650.0). Five patients with Alzheimer's disease as well as 5 controls had a history of rheumatoid disease. In two subjects with rheumatoid arthritis increased IL-6 levels $(94.0 \mathrm{U} / \mathrm{ml}$ and $650 \mathrm{U} / \mathrm{ml})$ may have been due to the fact that these patients suffered from rheumatoid arthritis. Upon exclusion of all patients with rheumatoid arthritis median levels of serum IL-6 were $8.6 \mathrm{U} / \mathrm{ml}$ (range: 4.6-34.0) for patients with Alzheimer's disease and $8.2 \mathrm{U} / \mathrm{ml}$ (range: $5.8-30.0$ ) for the controls (Fig. 2). In 5\% (4/74) of the controls the concentration of serum IL-6 was above $13.0 \mathrm{U} / \mathrm{ml}$; serum levels over $13.0 \mathrm{U} / \mathrm{ml}$ were found in twice as many Alzheimer patients $(11 \%=10 / 93$; $P<0.17$ ). Serum levels of IL-6 were similar for the 43 sporadic patients (those with no family history of dementia) and the 49 familial patients (those with one or more first degree relatives with dementia). Median levels of serum IL-6 were $8.6 \mathrm{U} / \mathrm{ml}$ (range: 4.6-34.0) for sporadic patients and $8.2 \mathrm{U} / \mathrm{ml}$ (range: 4.8-28.0) for familial patients $(P<0.42)$. High concentrations of IL-6 were not associated with the severity of the dementia measured by the clinical dementia rating scale or with the duration of the disease since the first symptoms.

Earlier studies have reported increased serum levels of acute-phase proteins in patients with Alzheimer's disease [3, 7]. In the present study of well-defined patients with clinically diagnosed Alzheimer's disease we do not obtain evidence for elevated serum levels of IL-6, one of the mediators of the acute-phase response, as compared to age- and sex-matched population controls. In some patients and controls elevated levels of IL-6 were found in serum. Since no obvious symptoms accounted for these findings, it is likely that subclinical inflammatory processes were responsible. Our findings do not exclude of course the possibility that the concentration of IL-6 is locally elevated within the central nervous system. Recently an increased number of IL-1 positive cells have been reported in patients with Alzheimer's disease and Down's syndrome [13]. Support for a local synthesis of IL-6 is provided by observations in mice [16]. It has been suggested that IL-6 may be involved in repair mechanisms by increasing the secretion of nerve growth factor by astrocytes [16]. Therefore, it is conceivable that IL-6 production, like IL-1, may be altered in Alzheimer's disease and further studies of levels of IL-6 within autopsy material will certainly be of interest.

This research was funded by the SOOM Foundation and carried out under the auspices of the Eurodem EC Concerted Action, The Netherlands. We thank Drs. Wim Schulte, Teun Tanja, Rob Haaxma, Arie Lameris, Rolf Saan for case diagnosis and case finding. 
I Abraham, C.R. and Potter, H., Alzheimer's disease: recent advances in understanding the brain amyloid deposits, Biotechnology, 7 (1989) 147-153.

2 Abraham, C.R., Selkoe, D.J. and Potter, H., Immunochemical identification of the serine protease inhibitor $x 1$-antichymotrypsin in the brain amyloid deposits in Alzheimer's disease, Cell, 52 (1988) 487-501.

3 Elovaara, I., Maury, C.P.J. and Palo, J., Serum amyloid A protein, albumin and prealbumin in Alzheimer's disease and in demented patients with Down's syndrome, Acta Neurol. Scand., 74 (1988) 245250.

4 Frei, K., Malipiero, U.V., Leist, T.P., Zinkernagel, R.M., Schwab, M.E. and Fontana, A., On the cellular source and function of interleukin 6 produced in the central nervous system in viral diseases, Eur. J. Immunol., 19 (1989) 689-694.

5 Ganapathi, M.K.,. May, L.T., Schultz, D. et al., Role of interleukin-6 in regulating synthesis of serum amyloid $\mathrm{A}$ and $\mathrm{C}$-reactive protein in human hepatoma cell lines, Biochem. Biophys. Res. Commun., $157(1988) 271-277$.

6 Geiger, T., Andus, T., Klapproth, J., Hirano, T., Kishimoto, T. and Heinrich, P.C., Induction of rat acute-phase proteins by interleukin 6 in vivo, Eur. J. Immunol., 18 (1988) 717-721.

7 Giometto, B., Argentiero, V., Sanson, F., Ongaro, G. and Tavolato, B., Acute-phase proteins in Alzheimer's disease. Eur. Neurol., 28 (1988) 30-33.

8 Glenner, G.G., Alzheimer's disease: its proteins and genes, Cell, 52 (1988) 307-308.

9 Hachinski, V.C., Lassen, N.A. and Marshall, J., Multi-infarct dementia: a cause of mental deterioration in the elderly, Lancet, ii (1974) 207-209.

10 Hofman, A., Schulte, W.. Tanja, T.A., Van Duijn, C.M., Haaxma, R., Lameris, A.J., Otten, V.M. and Saan, R.J., History of dementia and Parkinson's disease in first degree relatives of patients with Alzheimer's disease, Neurology, in press.

11 Housiau, F.A., Devogelaer, J.P., van Damme, J. et al., Interleukin-6 in synovial fluid and serum of patients with rheumatoid arthritis and other inflammatory arthritides, Arthritis Rheumatism, 31 (1988) 784788.

12 Hughes, C.P., Berg, L., Danziger, W.L., Coben, L.A. and Martin, R.L., A new clinical scale for the staging of dementia, Br. J. Psychiat., 140 (1982) 566-572.

13 Marx. J.L., Brain protein yields clues to Alzheimer's disease, Science, 243 (1989) 1664-1666.

14 McKhann, G., Drachman, D., Folstein, M., Katzman, R., Price, D. and Stadlan, E.M., Clinical diagnosis of Alzheimer's disease: report of the NINCDS-ADRDA Work Group, Neurology, 34 (1984) $939-944$

15 Moshaqe, H.J., Roelofs, H.M.J., van Pelt, J.F. et al., The effect of interleukin-1, interleukin-6 and its interrelationship on the synthesis of serum amyloid $\mathrm{A}$ and C-reactive protein in primary cultures of adult human hepatocytes, Biochem. Biophys. Res. Commun., 155 (1988) 112-117.

16 Nijsten, M.W.N., De Groot, E.R., Ten Duis, H.J., Klasen, H.J., Hack, C.E. and Aarden, L.A., Serum levels of interleuking- 6 and acute phase response, Lancet, ii (1987) 921.

17 O'Garra, A., Interleukins and the immune system 1, Lancet, i (1989) 943-947.

18 Pfeiffer, E., A short portable mental status questionnaire for the assessment of organic brain deficit in elderly patients, J. Am. Geriatr. Soc., 23 (1975) 43341.

19 Shegal, P.S., Helfgott, D.C., Santhanam, U. et al., Regulation of acute phase and immune responses in viral disease, J. Exp. Med., 67 (1988) 1951-1956.

20 Van Oers, M.H.J., Van der Heyden. A.A.P.A.M. and Aarden, L.A., Interleukin 6 (IL-6) in serum and urine of renal transplant recipients, Clin. Exp. Immunol., 71 (1988) 314-319.

21 Waage, A., Kaufmann, C., Espevik, T. and Husby, G., Interleukin-6 in synovial fluid from patients with arthritis, Clin. Immunol. Immunopathol., 50 (1989) 394-398. 